\title{
Transferability and Commercialization of Patent Rights: Economic and Practical Perspectives
}

\author{
Haim V. Levy*
}

\begin{abstract}
The transformation of innovation into commercial value depends primarily on appropriate protection of the intellectual property, usually by patents, and efficient pathway(s) of its transferability as well as the transfer of the protected knowledge. The key features of patents, from an economic perspective, are that they encompass new knowledge and confer monopoly rights to the owner. The exclusiveness of patent rights is generally conceived as a necessary mechanism to ensure further innovation, stimulate advanced research and facilitate efficient market transactions with patent rights. The patent holder can transfer the technology embodied by way of granting to others a license to use the patented invention in return for a share of the revenues, usually royalties. Patent rights transferability has been proven to be efficient and profitable to the industry as well as beneficial to the welfare of society. The economic and practical perspectives of the transferability and commercialization of patent rights are discussed.

Keywords: blocking patents, cross-licensing, exclusion right, intellectual property rights, innovation, knowledge, licensing, patents, patent pools, technology transfer, transferability.
\end{abstract}

\section{Introduction}

In general, the mobility of knowledge or innovation, including from universities and research institutes, to industry is described as 'technology transfer'[1]. I have indicated elsewhere that the exclusive nature of intellectual property rights is conceived to be essential and instrumental for efficient exchange transactions (Levy, 2011). I have further indicated that knowledge can be non-excludable since once it is made public,

* Dr. Haim V. Levy is the founder of two Biomed companies and currently serves as Chairman of NanoDerma Ltd. He lectures on Entrepreneurship at Ben Gurion University (Israel) and is business adviser and counsel to Hi-Tech transactions. hlevydr@ netvision.net.il.

1 More practically, technology transfer is defined, in economic terms, as the process by which a developer of knowledge or technological innovation and owner of intellectual property rights avails it to a business partner for more efficient commercial exploitation. 
in the absence of clearly defined and protected property rights, users cannot be prohibited from using it. The most common way of excluding knowledge is by patent protection. Therefore, many companies, particularly the large ones, have a decisive patent strategy aimed at protecting their proprietary technology thus giving their products an advantage over competing products.

Licensing of intellectual property rights can successfully and effectively bring protected innovation through to the market place. Efficient licensing transactions are dependent, among others, on the economic strength of the licensee, which is required to be financially, technologically and operationally competent to develop, manufacture and market innovation.

It is apparent that the transfer of property, in general, is a crucial driving force in a market economy. Correspondingly, the ability of a society to produce and commercialize knowledge (innovation) is critical for sustained economic growth and improved quality of life. Notably, the transformation of knowledge or innovation into commercial value depends primarily on its appropriate protection and successful transfer and acquisition.

This paper ensues the previous one (Levy, 2011) discussing the 'transformation of basic research into commercial value'. It is aimed at elaborating on the economic and practical perspectives of the transferability and commercialization of intellectual property rights, in particular scientific achievements and technological innovation.

\section{Theoretical and Economic Analysis of Tangible and Intangible Property Rights}

The consequence of property rights is well established in economic theory literature. However, they are defined inconsistently in the economics literature and economists sometimes define property rights in ways that diverge significantly from the conventional legal paradigm. See, for example, (Cole \& Grossman, 2000).

In their fundamental paper in law and economics school, Calabresi and Melamed present a framework which basically describes all legal transferable ${ }^{[2]}$ entitlements as protected by either Property rules or Liability rules (Calabresi \& Melamed, 1972). An entitlement to private property is protected by property rules (decided by a government agency) to the extent that one cannot remove such entitlement without paying the value decided and agreed upon by the holder itself, ex-ante. Most real estate, for example, is protected by this class of entitlement.

To the contrary, entitlements protected by liability rules allow non-holders to infringe or transfer an entitlement as long as that they adequately compensate it expost, on the basis of damages determined by court ${ }^{[3]}$. Liability rules are beyond the scope of this paper and are thoroughly discussed in the literature ${ }^{[4]}$. In this paper I limit the discussion to property rules with implication on intellectual property rights.

2 Non-transferrable entitlements are protected by Inalienability rules.

3 Note that common contract law provides another example of a liability rule whereby parties to a contract can breach it, so long as they pay ex-post court-determined damages (or by alternative dispute resolution (e.g., arbitration, mediation approach).

4 For suggested reading, see e.g., (Coase, 1960); (Calabresi \& Melamed, 1972); (Kaplow \& Shavell, 1996); (Cole \& Grossman, 2000). 
In the economic literature, the term "property right" carries an additional meaning implying the ability of the holder to gain from its property, by consumption or exchange. Barzel has designated it as "Economic Property Right" (Barzel, 1977), as opposed to "Legal Property Right", discussed above. Transaction cost is closely associated with the economic property right, and encompasses transfer, capture and protection of the property right. In order that the rights to a property complete or become perfectly delineated, both the holder of the right and the party interested in the property right must possess complete information on its attributes. Availability of complete information facilitates the transfer of the entitlement to be readily consummated. Evidently, high transaction cost would prohibit the transfer of the property right. In practice, there are positive transaction costs, thus the allocation and implication of entitlement is significant as it can ultimately affect social product.

The above introductory discussion on property rights is applicable, to the extent described below, also to intangible property. Intangible or intellectual property rights are defined by The Convention Establishing the World Intellectual Property Organization (WIPO) ${ }^{[5]}$ as follows: "Intellectual Property shall include rights relating to literary, artistic and scientific works; performances of performing artists, phonograms and broadcasts; inventions ${ }^{[6]}$ in all fields of human endeavor; scientific discoveries ${ }^{[7]}$; industrial designs; trademarks, service marks and commercial names and designations; protection against unfair competition; and all other rights resulting from intellectual activity in the industrial, scientific, literary or artistic fields".

In this paper I purposely limit the discussion to inventions, which are usually protected by patents. A patent is an intellectual property right granted by a national government agency to an inventor to exclude others from making, using, offering for sale, or selling the invention throughout the country or importing the invention into the country for a limited time in exchange for public disclosure of the invention when the patent is granted. Patents are therefore valid in individual countries for specified periods, usually for twenty years ${ }^{[8]}$. They are generally granted by a national patent office or a regional one like the European Patent Office (EPO) ${ }^{[9]}$.

Interestingly, the origin of modern patent law can be traced to the late sixteenth century. Monopoly grants were issued through a royal legal device known as a "letter

5 Concluded in Stockholm on July 14, 1967 (Article 2(viii))

6 "Inventions are new solutions to specific technical problems. Such solutions must, naturally, rely on the properties or laws of the material universe (otherwise they could not be materially or "technically" applied), but those properties or laws need not be properties or laws "not hitherto recognized." An invention puts to new use, to new technical use, the said properties or laws, whether they are recognized ("discovered") simultaneously with the making of the invention or whether they were already recognized ("discovered") before, and independently of, the invention". (Cited from: http:// www.wipo.int/export/sites/www/about-ip/en/iprm/pdf/ch1.pdf)

7 Scientific discoveries are not the same as inventions. The Geneva Treaty on international Recording of Scientific Discoveries (1978) defines a scientific discovery as "the recognition of phenomena, properties or laws of the material universe not hitherto recognized and capable of verification" (Article 1(1)(i))

8 The claimed invention appears to be novel, to involve an inventive step (to be non-obvious), and to be industrially applicable (Utility) [see e.g., United States Code Title, Chapter 10, Sections 35 U.S.C. 101-103; Patents Patent Cooperation Treaty - PCT Article 33(1)-(4)].

9 http://www.epo.org/index.html 
patent $^{\prime \prime[10]}$ (for further reading see e.g., (Mossoff, 2001)). Two-hundred years later, patents became explicit legal tools for promoting and protecting an inventor's property right in his or her creation. Nowadays, it is beyond doubt that patents are property rights as patents secure only the right to exclude ${ }^{[11]}$ - ius excludendi alios. This is derived from a conception of property in land and other tangible property interest, and became the standard definition of legal entitlements in property comprising a right to exclude ${ }^{[22]}$.

Patent scholars have adopted the exclusion concept of property in land, and to a certain extent to chattels, and have similarly redefined the patent law ${ }^{[13]}$. Chisum states that "a patent grants to the patentee and his assigns the right to exclude others from making, using, and selling the invention. ...t does not grant the affirmative right to make, use or sell...." (Chisum, 2006). Markedly, unlike other forms of property, a patent includes only the right to exclude and no other rights, see, for example, (Merges \& Duffy, 2007); while property rights pertaining to land and chattels secure the traditional "bundle of rights"[14]. Apparently, patents are conceptually differentiated from land because of seemingly important doctrinal differences between the enforcement of tangible and intangible property entitlements (Wlaterscheid, 2005).

The validity of the exclusion doctrine of patents may be demonstrated in the phenomenon of 'blocking patents'. A blocking patent exists when two separate patents cover aspects of the same invention, and thus each patentee can exercise their right to exclude the other patentee from using their respective contribution to this invention ${ }^{[15]}$ (see also discussion on cross-licensing and patent pools in Section $[3$, below). Such situations are quite common, thus prior inventors are able to exclude consequent commercial applications of their inventions. Some scholars however tend to view the blocking patent scenario as evidence of the distinction between property and exclusive patent rights (Mossoff, 2009). Notably, there is no parallel example to the blocking patent in the domain of tangible property, which is why blocking patents are cited as evidence of the conceptual distinctiveness of patents as property.

It should be mentioned that the exclusion concept of patents and its influence on modern patent doctrine has been criticized in the literature. Mossoff, for instance, suggests reconsidering both the substance and significance of the conceptual analysis

10 "The crown's prerogative to issue letters patent was a central tool in bestowing privileges upon individuals in the furtherance of royal policies."

11 The right to exclude is also interpreted as allowing the owner that alleges patent infringement to ask before a court not only damage compensation but also remedies that aim at stopping the infringing activity, mainly, injunctive relief. In a way, it is similar to land boundaries and trespass.

12 For example, as promulgated within The American Patent Act 1952.

13 Note that I purposely mostly refer to the abundant literature and scholars views vastly available with respect to the common law and the American patent law.

14 i.e., the right to exclude; the right to transfer; and the right to possess and use.

15 For example, say inventor $A$ discovered a new drug $X$ and was granted a patent; inventor $B$ discovered a process to make $X$ and was granted a patent on the process. Inventor $A$ can exercise its right to exclude inventor $B$ from making the drug $X$. In this situation, A has a "blocking patent," because it can block B to use of its own patented process. A seems to have a greater scope of exclusivity as it can produce the drug in a different process, if available, without infringing B's patent. 
of patents as property (Mossoff, 2009). The question whether an intellectual property right is actually more than an 'exclusion right' is worthy to be briefly considered, in particular vis-à-vis the ownership and transferability of the intellectual property right, which is the subject matter of this paper. In brief, legal positivism arguments suggest that creators, in addition to their copyright, may be entitled to a reward based on a 'moral right'. European and other intellectual property laws convey a "moral right" to creators in connection with the 'commercial' copyrights; see, for instance, French copyright law. I reason that the necessity for an additional moral right is to complement the economic property right ${ }^{[16]}$ (which entitles the creator to gain from the protected right) with what I define as a 'social property right', aimed at additionally entitling the creator with recognition by society and dignity, for example, a book will always bear the name of the author ${ }^{[17]}$. Contrary to the property right, the moral right is not and should not be transferrable. It should be pointed out that 'moral right' is uncommon in patent treaties ${ }^{[18]}$. To this end, I propose to consider a 'moral right' in context of economic property right, which is virtually protected by patents. This concept will be discussed in a forthcoming paper.

The key features of patents, from economic perspectives, are that they encompass new knowledge and they confer monopoly rights to the owner that arise from the right to exclude. The patent related monopoly right is controversial and vastly discussed in the literature, see, for instance, (Kaplow, 1984); (Posner, 2005); (Nordlin \& Levine, 2008)). It is worth noting that modern antitrust policy follows the general prohibition of monopolies while modern patent law succeeded the exemption. The conflict between antitrust law and patent policy has persistently perplexed jurists. It has been argued that the monopoly right purpose is to ensure further innovation and knowledge which are critical for sustained economic growth and improved quality of life and welfare. Posner distinguishes between 'legal' and 'economic' monopoly. A legal monopoly is not necessarily an economic monopoly. It is evident to assume that a patent can be used as a lever to obtain power over the price of unpatented products that are complements of the patented products. Furthermore, patented products do not confer a power over the price of substitutes, which are not patented products (Posner, 2005). Others argue against intellectual property monopoly suggesting that monopolies work to move the wealth to the monopolists, most easily accomplished by blocking innovation and productivity growth as monopolists will do everything necessary to retain their profits (Nordlin \& Levine, 2008) ${ }^{[19]}$.

16 Arising from the exclusion right

17 From legal perspectives infringing the moral right may entitle the creator to compensation, that in addition to damages for the infringement of copyrights. (See also infra note 31).

18 Firstly, patents are disclosed to the public and include the names of the inventors. Secondly, inventors (patent holders) may publish, in the scientific and technical literature the invention or technology embodied in the patent. In both ways the inventor(s) [creator(s)] will gain recognition and dignity without the protection of a moral right.

The authors designate this phenomenon as "IP inefficiency" 
Indubitably, the conflict between patent and anti-trust policies reveals the inherent contradiction among the private and the public interests. Nonetheless, patent law should offer a balance between the freedom to use existing ideas and the incentive to innovate and create new ones.

In economic terms, the excludability right inherent in patents is generally conceived as a necessary mechanism to ensure innovation, urge further research and facilitate efficient market transactions with patent rights, as well as other intellectual property rights, see also (Landes \& Posner, 2003). It is therefore argued that absent of exclusion rights, an inventor may bear all the costs of the creation of a commercially valuable invention, or other creative outcome (e.g., music) while everyone has an incentive to free ride, exploit and benefit from this innovation, at no cost and with no strings attached.

Apparently, there is a consensus in the literature of economic analysis of intellectual property rights that they enable owners to gain return on their investment made in creating, inventing and developing new and improved products and technologies. Intellectual property in all forms is in fact considered one of the major drivers of innovation in 'knowledge-based economies' - economies which are directly based on the production, distribution and use of knowledge (OECD, 1996). Seemingly, in absence of excludability rights knowledge-based economy growth would be attenuated ${ }^{[20]}$.

The economic significance and awareness of the value of patent protection is demonstrated in the WIPO's report on 'World Intellectual Property Indicators' (WIPO, 2011). Consequently, "patent filings worldwide have reached historically unprecedented levels. The numbers of filings at the largest patent offices were stable until the 1970s, but then saw substantial growth". Patent subject matter has expanded over the past decades to include biotechnology, software and, in some countries, methods of doing business. Figure 1 demonstrates the increase in the number of patent applications ${ }^{[21]}$ during the past twenty five years.

According to WIPO, the increase in patent applications may indicate accelerated technological progress and thereby generating economic prosperity. It may also reflect the changing nature of innovation systems (WIPO, 2011). Increased international commerce and the vital need for companies to protect their knowledge in international markets are a third important factor. The number of patents granted during same period is shown in Figure 2. I argue however that the 'Total number of patents' does not necessarily imply on the strength of the patents (e.g., validity; firm and durable claims), their commercial value or commercial exploitation.

20 It should be noted that knowledge can be non-excludable, since once it is made public, in the absence of clearly defined and protected property rights, users cannot be prohibited from using it. Some forms of knowledge are (or can be made) excludable. For instance, it may be possible to keep new knowledge secret ('trade secret'), thereby excluding use by others. The most common way of excluding knowledge is by seeking protection through patents. Nonetheless, certain advances in basic knowledge, such as mathematical theorems, are not patentable despite their importance and their potential practical applications. 


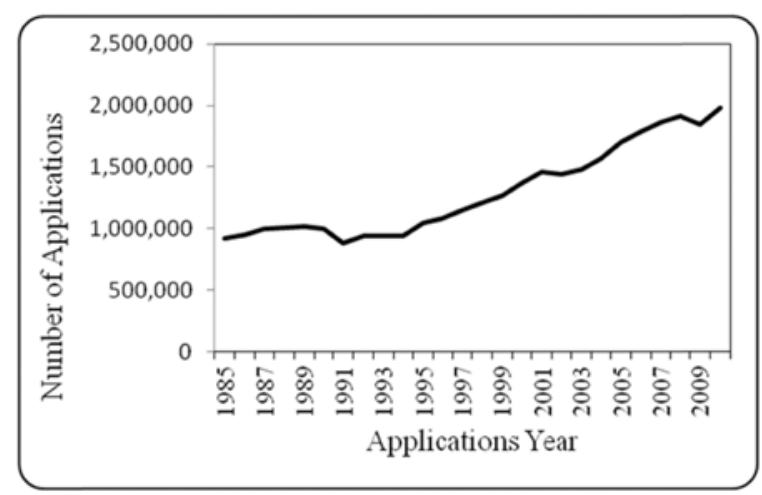

Figure 1. Trend in Total Patent Applications (1985-2010) Source: WIPO Statistics Database, October 2011

Therefore, I propose that the latter parameters be considered and taken into account when referring to 'total number of patents' as an indicator for generating economic prosperity in knowledge based economy. As a matter of fact, it is evident that numerous patents are not and may never be used or exploited commercially. I aim to address this matter in a forthcoming paper.

\section{Economic and Practical Analysis of Patent Right Transferability}

As abovementioned, unlike other forms of property, a patent includes only the right to exclude and no other rights; whereas property rights pertaining to personal property, such as land and chattels, also secure the exclusive rights of possession, use and disposition. One of the significant rights in this bundle is the right to transfer the holder's property right to other ${ }^{[22]}$. Patents as well have the attributes of personal property. Consequently, applications for patent and patents are assignable in law. The applicant or patentee may grant and convey an exclusive (or non-exclusive) right under his or her application for patent or patents ${ }^{[23]}$.

22 It should be noted that property laws impose various restrictions on this right. For example, condition to "never sell the land" imposes an invalid condition.

23 See e.g., US patent law, 35 U.S.C. 261; UK Patents Act (1977) 


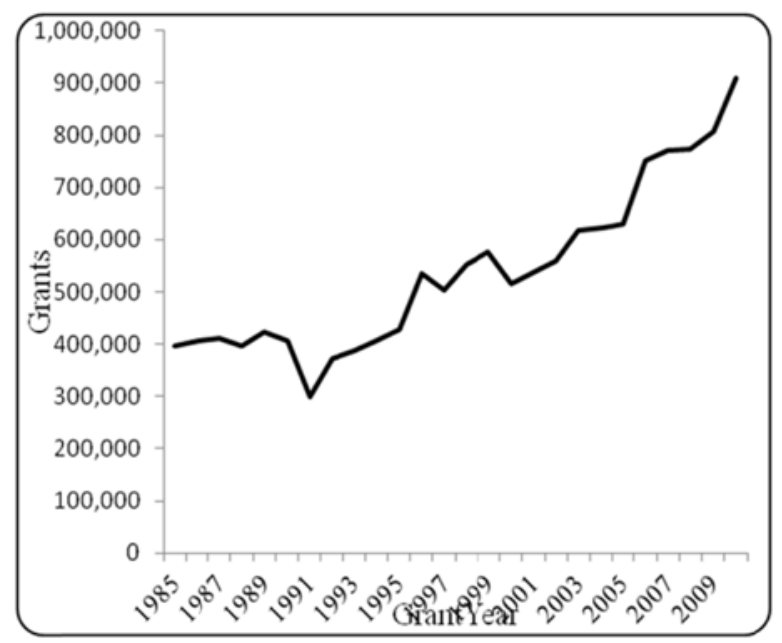

Figure 2. Trend in Total Patent Grants (1985-2010)

Source: WIPO Statistics Database, October 2011

It should be noted that granting a license per sē is not assigning the title to the right itself but rather granting the licensee a permission to use the invention, which is interpreted as a contractual commitment ('covenant') not to sue for an alleged infringement ${ }^{[24]}$. Hence, the licensor remains the owner and holds title to the invention. The owner may however choose to assign his or her ownership entitlement to others, pursuant to certain legal procedures and deeds ${ }^{[25]}$, for a fair market value.

Ownership of the patent rights presents material legal and economic implications worthy to be briefly addressed herein. It is now a common policy and practice in developed countries that employers, as well as universities, claim and retain title to inventions made by their employees, including faculty scientists, during the course of their work. This is implemented either by legislation or contractually (i.e. employment contracts). I argue in the previous paper (Levy, 2011) that a more broad strategy should be endorsed, according to which the ownership of intellectual property rights should neither depend on the source of funding nor on the nature of the employer but rather should be determined by and depend on the employer-employee labor relations in general. Such policy is implemented, for instance, in the Israel Patent Law ${ }^{[26]}$ and the UK Patent Act ${ }^{[27]}$.

It is evident that transfer of property, in general, is a crucial driving force from market economy perspective. Correspondingly, the ability of a society to produce and

\footnotetext{
24 The remedies which may be available to the patent owner where infringement has been established are usually provided for in the national patent law and are generally in the form of civil sanctions, including the award of damages, the grant of an injunction or any other remedy provided in the general law. 
commercialize knowledge (innovation) is critical for sustained economic growth and improved quality of life. Recent policy statements from the OECD, the World Bank, and others, clearly echo that knowledge is the most important factor in economic development. The role it plays in the process of innovation and economic growth has become even more central since the emergence of the knowledge-based economies enabled, among others, by technology transfer. Evidently, the transformation of knowledge or innovation into commercial value depends primarily on its successful transfer and acquisition.

There is an apparent universal interest in commercially exploiting viable inventions. On one hand, owner of patent rights seeks to at least return his or her investment, on the other hand, potential "infringers" seek out to improve their products or develop new ones using the invention at no cost. The patent holder can exploit the invention exclusively or can transfer the technology embodied by way of granting a license to use the patented invention to others (during the life of a valid patent) in return for a share of the revenues, normally royalties. The strength of patents (i.e. legal and economical) may be critical to the holder's decision to license new technologies rather than to use them exclusively. It is argued in the literature that in facilitating technology transferability patents may be self-correcting. A stronger legal right to exclude others from using an invention generally provides a stronger economic incentive to include them through licensing, as infringement may result in costly law suits or settlements. Whereas weak patented inventions can disseminate through non-infringing imitations or through royalty based licenses offered to discourage costly imitation by competitors (Gallini, 2002). Apparently, the economic value and the strength of the protected invention determine its transferability cost.

The transfer of the intellectual property right will impose costs on both parties attempting to determine the value of its attributes, the consequences of which was discussed above. Among others, one particular concern is the "freedom to operate", namely, the ability to develop, make, and market products without legal liabilities to third parties (i.e. patent holders). Consequently, it is crucial to conduct freedom to operate analyses prior to a licensing, acquisition of patents or investment transactions in technology based companies. Similarly, freedom to operate analyses should be conducted in case several potential research pathways are feasible so as to allow selection of pathway with the least dependence on third-party patents in order to avoid potential litigation, due to infringement, or pay licensing royalties.

Patents enable companies to maintain and defend a market advantage ${ }^{[28]}$. Many companies, particularly the large ones, have a patent strategy aimed at protecting the proprietary technology thus giving their products an advantage over competing

28 It should be noted that companies' intellectual property management can be divided into two areas. The first concerns internal management (disclosures, patent applications, maintenance, etc.). The second concerns external management, primarily how a company interacts with other companies' intellectual property rights and vice versa; as well as monitoring possible infringements and initiate litigation process. 
products. Moreover, companies' research and development (R\&D) strategy is often driven by the potential strength of their patents. Indubitably, nowadays companies are urged to develop, or acquire, a sustained patent portfolio.

A recent vivid example that demonstrates the materialization of such strategy is the recent transaction in which Microsoft acquired from AOL more than 800 patents for $\$ 1.056$ billion in cash ${ }^{[29]}$. This remarkable transaction reflects the crucial role that patents are increasingly playing in the business of the world's leading technology companies.

It should be pointed out that different industries vary greatly in how they approach innovation and the importance of innovation to sustained growth. The pharmaceutical industry exemplifies this paradigm. In this industry, a patent represents only the beginning of a long and particularly costly process of developing a marketable medicine. It is a common knowledge that the development of new drugs (and medical innovations in general) requires massive long term investments in R\&D, expertise in pharmaceuticals development, obtaining regulatory approval, production and marketing capacities. On average, developing an innovative new drug takes about 12 years. A recent estimate of the average cost of developing an innovative new drug is over $\$ 800$ million, including expenditures on failed projects and the value of forgone alternative investments (DiMasi, Hansen, \& Grabowski, 2003). Large pharmaceutical companies find viable innovation to be much more difficult to accomplish internally (Christensen, 1997). The challenges, including, among others, lack of in house basic research set-up and activities, encourage large pharmaceutical firms to pursue collaborative alliances. Majority of these alliances materialize through licensing transactions with university scientists and small spin-off companies ${ }^{[30]}$. Some remarkable licensing instances of basic research in the medical field from academia in Israel to industry are shown in Table 1. Pharmaceutical executives seem to recognize that collaborative arrangements provide a vital mechanism enabling to expand product pipeline. With fewer new drugs coming to market and proprietary drugs losing their market protection from generics, big companies switched to mergers and acquisitions for continued growth, inter alia, by acquiring patent rights to proprietary drugs ${ }^{[31]}$.

See AOL press release - http://corp.aol.com/2012/04/09/aol-and-microsoft-announce-1-056-billion-patent-deal/ GlaxoWellcome's 2000 acquisition of SmithKline Beecham was valued at $\$ 74$ billion. Other large deals included SanofiSynthelabo's $\$ 65.5$ billion acquisition of Aventis in 2004; Merck \& Co.'s acquisition of Schering-Plough for \$41.1 billion in 2009; and Bayer AG's $\$ 21.5$ billion acquisition of Schering AG in 2006. I should point out, however, that while mergers and acquisition among pharmaceutical companies seems to be beneficial to both parties, the outcome of mergers and acquisition in the pharmaceutical-biotechnology industry seems to have failed. It is estimated that trillion dollars in the market value were erased in the past decade. This fact can be partially explained by failure of clinical trials and discontinuing R\&D projects. 
Table 1. List of Licensed innovative Drugs from Universities in Israel

\begin{tabular}{lllcl}
\hline \multicolumn{1}{c}{ Product } & \multicolumn{1}{c}{ Indication } & \multicolumn{1}{c}{ Licensee } & $\begin{array}{c}\text { Sales in 2011 } \\
\text { (in millions) }\end{array}$ & \multicolumn{1}{c}{ Licensor } \\
\hline Copaxone & Multiple Sclerosis & Teva & $\$ 3,570$ & Weizmann Institute (WI) \\
Rebif & Multiple Sclerosis & Merck-Serono & $€ 1,691$ & WI \\
Exelon & Alzheimer & Novartis & $\$ 1,067$ & Hebrew University (HU) \\
Doxil[a]/Caelyx & Cancer & Schering-Plough & $\$ 320^{[b]}$ & HU and Hadassah Hospital \\
Aziltec & Parkinson & Teva & $\$ 290$ & Technion Medical School \\
Erbitux & Cancer & Merck-Serono & $€ 855$ & WI \\
\hline
\end{tabular}

Sources: Companies' Annual Reports 2011

[a] Sold by Johnson \& Johnson (through its acquisition of Alza) in the United States and Schering Plough (under the trade name Caelyx) internationally. Source: http://www.zoominfo.com/\#!search/profile/ person?personld=1059435901\&targetid=profile.

[b] In 2010, Source: http://www.evaluatepharma.com/Universal/View.aspx?type=Entity\&entityType=Product\&id=12704\&IType $=$ modData\&componentID=1002.

In many industries companies license a product patent(s) for productive efficiency reasons, particularly, to achieve lowest manufacturing and distribution costs and yet gain from permitted production and sales by third parties. It is likely that a patent holder, which manufactures and sells a protected product, may not be situated to supply the market demand or to export to other territories due to shortage of production facilities, distribution setup or adequate finance to expand its operation. It is therefore a common practice that large established companies license out the production and sales of their patented product to third parties for generating more revenues, sometimes even to competitors ${ }^{[32]}$. For instance, in the computer industry IBM's know-how along with intellectual property assets reaches into nearly every industry and every discipline of science and technology. IBM's revenues from intellectual property and custom development income reached over $\$ 1.1$ billion $^{[33]}$ in 2011 , accounting for circa 7 percent of IBM's net profit. The noteworthy feature is that often large companies license their protected technology and knowhow to potentially competitors.

A well-known illustrative and worth noting example of licensing to potential competitors is the case of VCR (Video Cassette Recorder) technology ${ }^{[34]}$. In 1975 Sony introduced the Betamax, a proprietary technology, which represented a breakthrough on the VCR market. A year later, a competing (apparently lesser than Betamax)

32 Interestingly, an OECD report revealing statistical data shows that licensing markets (related to Europe and Japan) are less developed than they could be, in view of the willingness of patent holding companies to license more of their portfolio (Zuniga \& Guellec, 2009): “About $20 \%$ of European companies and $27 \%$ of Japanese companies holding patents license out at least one of their patents to an unaffiliated partner. The relationship between size and probability to license out among patent holding companies is U-shaped: the smallest ones and the largest ones are more often involved in licensing out than medium-sized ones. The highest proportion of firms license-out in Europe is found in the UK, followed by Nordic countries. Cross-licensing out is the second motive for licensing out, both in Europe and in Japan: that shows a role played by patents in technology exchanges between companies".

33 That includes $\$ 309$ million from sales and other transfers of intellectual property; $\$ 211$ million from Licensing/royaltybased fees and Custom development income contributed \$588 million, in total \$1,108 million. Source: IBM 2011 Annual Report. presentations/VCR-Battle-handout.pdf. 
technology, VHS (Video Home System) was introduced by JVC (Victor Company of Japan, Ltd.). The strategy of JVC and Matsushita Electric International (Panasonic) was aimed at creating an alignment of producers and gaining market share. The two companies agreed to ship original equipment manufacturer (OEM) VCRs to their licensees and then to further development of the VHS system. This helped the two companies to gather numerous partner companies around them, whereas Sony's approach to exclusively use its technology was seen by most as uncooperative. The outcome was that in 1978 all major European producers adopt VHS standard and in 1984 US partner Zenith abandons the Betamax format. Betamax format has practically become obsolete. Albeit this case undoubtedly reveals a remarkable business strategy, it similarly demonstrates the economic impact and significant contribution of technology transfer or from legal perspectives transferability of intellectual property rights in general, and to competitors, in particular.

An additional notable approach is the 'cross-licensing'. Accordingly, two (or more) companies grant each other cross-licenses to all technology developed by either party during a defined period with corresponding payments being made to cover any deficit in the value of technology licensed by one side or the other. Consequently, crosslicensing allows freedom to operate for each party ${ }^{[35]}$. This approach, for instance, is common among Japanese electronics companies.

One noteworthy example of an open cross-licensing transaction illustrates the transfer of technology from Japan to Asia. In the early nineties Samsung Electronics and Fujitsu entered a broad cross-licensing agreement that allowed each access to the other's microchip technologies patented in the US, Japan and Europe. Under the agreement Samsung paid Fujitsu $¥ 4$ billion to compensate for Fujitsu’s technological edge. This was some 25 percent of Samsung's 1991 pre-tax profits and the first time that Fujitsu had received royalties from a Korean firm in a cross-licensing agreement (Miyake, Yoshikawa, \& Inoue, 1992). It can be safely stated that cross-licenses may be especially useful in industries, such as the semiconductor and computer industries that are characterized by large numbers of overlapping patent rights

An additional related licensing arrangement is known as 'patent pools', which generally are created when a group of patent holders each decides to license its respective patents to each other and to third parties collectively. In many industries, the patent rights necessary to commercialize a product are often controlled by several rights holders. This can increase the transaction costs of negotiating multiple licenses and greater cumulative royalty payments. They are often formed when multiple patented technologies are needed to produce a standardized product or to solve the blocking patents situation. Pools composed only of complementary patents tend to

35 I should point out that one may argue that in certain legal jurisdiction cross-licenses provisions may allegedly violate anti-trust laws. My surmise however, that such claim is not self-evident. In 1995, the U.S. Department of Justice and U.S. Federal Trade Commission issued its "Antitrust Guidelines for the Licensing of Intellectual Property," which explicitly noted, cross-licensing and pooling arrangements may provide pro-competitive benefits (http://www.usdoj.gov/atr/public/guidelines/ ipguide.htm). However, provisions in portfolio cross licenses that may facilitate price fixing, for example, can raise antitrust concerns. 
increase efficiencies and lower prices to consumers. However, it is argued that pools composed of pure substitute patents, are more likely to harm social welfare than are pools of complementary patents (i.e., that do not compete with each other). Seemingly, the current form of patent pools that have been approved by the U.S. Department of Justice (see Chapter 3: Antitrust analysis of portfolio cross-licensing agreements and patent pools in guideline (2007)) have been highly beneficial to the public, with no apparent anticompetitive effects ${ }^{[36]}$. The Japanese Guidelines for the 'Use of Intellectual Property under the Antimonopoly Act' provides an additional supportive case ${ }^{[37]}$. A representative example is the MPEG-2 patent pool, where in spite of the patent pool competition did not cease, to the contrary, companies have and continue to develop new digital video standards ${ }^{[38]}$ (for further reading on patent pools efficiency, see e.g., (Lerner \& Tirol, 2004).

In summary, patents enable companies to maintain and defend a market advantage over competitors. In many industries companies license a product patent(s) for productive efficiency reason, particularly, to achieve lowest manufacturing and distribution costs and yet gain from permitted production and sales by third parties. However, when the patent rights necessary to commercialize a product are controlled by several holders of rights they will often prefer to cooperate and share patented knowledge through cross-licensing and patent pools. The various licensing approaches have been profitable not only to the companies but also have been highly beneficial to the public.

\section{Conclusions}

Unlike tangible property right, which includes the right to exclude as well as a bundle of other rights, intangible property or intellectual property right includes only the right to exclude. The exclusiveness nature of patent rights is conceived to be essential and instrumental for efficient exchange transactions. From economic perspective, the right to exclude confers (quasi) monopoly rights to the owner to prevent others from commercially exploiting the protected knowledge (invention). I agree with the conception that the (quasi) monopoly right purpose is to ensure further innovation and knowledge which are critical for sustained economic growth and improved quality of life and welfare.

The patentee (or patent applicant) may grant to others, by way of a licensing arrangement, a right under his or her patent application(s) or patent(s) to use make and sell a protected product (invention). In economics terms, the developer of knowledge or technological innovation and owner of intellectual property rights avails it to an appropriate business (strategic) partner for more efficient commercial exploitation.

36 See e.g., James J. Kulbaski, Comments on Patent Pools and Standards for Federal Trade Commission Hearings Regarding Competition \& Intellectual Property (Apr. 17, 2002 Hearing R.) at, http://www.ftc.gov/opp/intellect/020417jamesjkulbaski. pdf.

http://www.jftc.go.jp/en/legislation_guidelines/ama/pdf/Patent_Pool.pdf.

such as MPEG-4 and MPEG-7 that are advantageous over MPEG-2. 
It should be noted that universities have become more important players in knowledge-based economies and scientists, researchers and engineers have played a critical role in driving technological progress and innovation. It is evident that for universities technology transfer by way of licensing out ${ }^{[39]}$ can successfully and effectively bring their innovation through to the market place.

Nowadays companies are urged to develop, or acquire, a sustained patent portfolio. In industries where blocking patents exist, such as the semiconductors, companies exchange and use knowledge and technology among themselves via two efficient instruments, cross-licensing and patent pools. These patent rights transferability approaches have been proven to be efficient and profitable to the companies as well as beneficial to the welfare of society.

To conclude, the role technology transfer plays in the process of innovation and economic growth has become more central since the emergence of the so-called knowledge-based economies. Moreover, the transformation of patented knowledge and innovation into commercial value depends primarily on strong intellectual property rights and efficient transfer and acquisition.

\section{References}

Barzel, Y. (1977). Economc anlysis of property rights. NY: Cambridge University Prees.

Calabresi, G., \& Melamed, D. A. (1972). Property Rules, Liability Rules, and Inalienability: One View of the Cathedral. Harvard Law Review, (85), 1089-1128.

Chisum, D. S. (2006). Chisum on Patents § 16.02[1].

Christensen, C. (1997). The Innovator's Dilemma. Harvard Business School Press, Boston,Mass.

Coase, R. H. (1960). The Problem of Social Cost. Journal of Law and Economics, 3, 1-44.

Cole, D. H., \& Grossman, P. Z. (2000, July 19). The Meaning of Property 'Rights': Law vs. Economics? Available at SSRN: http://ssrn.com/abstract=219408.

Deazley, R. (2008). 'Commentary on early Tudor printing privileges 1553', in Primary Sources on Copyright (1450-1900). Retrieved from eds L. Bently \& M. Kretschmer: www.copyrighthistory.org.

DiMasi, J. A., Hansen, R. W., \& Grabowski, H. G. (2003). The Price of Innovation: New Estimates of Drug Development. Journal of Health Economics, 22, 2, 151-185.

Dworkin, R. M. (1977). Taking Rights Seriously. Cambridge, MA: Harvard University Press.

Gallini, N. T. (2002). The Economics of Patents: Lessons from Recent U.S. Patent Reform. Journal of Economic Perspectives, 16, 2, 131-154.

Justice, D. (2007). U.S. Dep't of Justice \& Fed. Trade Comm'n, Antitrust Enforcement and Intellectual Property Rights: Promoting Innovation and Competition. www.usdoj.

39 In circumstances where the innovation is at an early stage and far from materializing to a product, licensing is not always plausible; Universities' technology transfer office should therefore explore alternative avenues, such as formation of spin-off companies. 
gov/atr/public/hearings/ip/222655.pdf: U.S. Department of Justice and the Federal Trade Commission.

Kaplow, L. (1984). The Patent-Antitrust Intersection: A Reappraisal. Harvard Law Review, $97,8,1813-1892$.

Kaplow, L., \& Shavell, S. (1996, Feb.). Property Rules versus Liability Rules: An Economic Analysis. Harvard Law Review, 109, 4, 713-790.

Landes, W. M., \& Posner, R. A. (2003). The Economic Structure of Intellectual Property Law. Harvard University Press.

Lerner, J., \& Tirol, J. (2004). Efficient patent pools. American Economic Review 94, 691711.

Levy, H. V. (2011). The Transformation of Basic Research into Commercial Value: Economics Aspects and Practical Issues. Journal of Entrepreneurship, Management and Innovation, 7, 4-15. Retrieved from Available at SSRN: http://ssrn.com/ abstract=2010577.

Long, P. O. (1991). Invention, authorship, 'intellectual property' and the origin of patents: notes toward a conceptual history. Technology and Culture, 32, 4, 846-884.

Merges, R. P., \& Duffy, J. F. (2007). Patent law and Policiy (4th ed.).

Miyake, S., Yoshikawa, K., \& Inoue, Y. (1992, April 27). Chipmakers wielding patents in global competition. Nikkei Weekly 1, 19.

Mossoff, A. (2001). Rethinking the Development of Patents: An Intellectual History, 15501800. Hastings Law Journal 52. Available at SSRN: http://ssrn.com/abstract=863925, 1255-1322.

Mossoff, A. (2009). Exclusion and Exclusive Use in Paten law. Harvard Journal of Law \& Technology, 22, 2, 321-379.

Nordlin, M., \& Levine, D. K. (2008). Against Intellectual Monopoly. Cambridge university Press.

OECD. (1996). The knowledge-based economies. Paris: OECD.

Patterson, L. R. (1968). Copyright in Historical Perspective. Nashville: Vanderbilt University, 20.

Posner, R. A. (2005). Intelectual Porperty: The Law and Economic Approach. Journal of Economic Perspectives, 19, 2, 57-73.

Schippe, H. (2001). Die Anfänge des Erfinderschutzes in Venedig. In U. Lindgren, Europäische Technik im Mittelalter. 800 bis 1400. Tradition und Innovation (pp. 539550). Berlin: Mann Verlag ISBN 3-7861-1748-9.

WIPO. (2011). World Intellectiual Property Indicators.

WIPO, I. P. (2011). World Intellectual Property Report. WIPO.

Wlaterscheid, E. C. (2005). Divergent Evolution of the Patent Power and the Copyright Power. Intellectual Property Law Review, 307-330.

Zuniga, M. P., \& Guellec, D. (2009). Who Liceneses out patents and why?Lessons from a business survey. OECD. 


\begin{abstract}
Polish)
Przekształcenie innowacji w wartość handlowq zależy przede wszystkim od odpowiedniej ochrony własności intelektualnej poprzez patenty oraz wydajnej organizacji transferu chronionej wiedzy. Kluczowq cechq patentów, z perspektywy ekonomicznej jest to, że obejmujq one nowq wiedzę oraz przyznaja prawa wyłquczności właścicielowi. Wyłączność praw patentowych jest zazwyczaj postrzegana jako konieczny mechanizm dla zapewnienia dalszej innowacyjności, stymulowania zaawansowanych badań oraz ułatwiania wydajnych transakcji rynkowych dotyczqcych praw patentowych. Właściciel patentu może przekazać objętq patentem technologię poprzez przyznawanie zainteresowanym licencji $z$ prawem wykorzystania opatentowanego wynalazku $w$ zamian za odpowiedniq gratyfikację. Transfer praw patentowych jest postrzegany jako wydajne i rentowne przedsięwzięcie zarówno dla przemysłu jak sytuacji materialnej społeczeństwa. Przedmiotem dyskusji sq perspektywy ekonomiczne i praktyczne tranferu i komercjalizacji praw patentowych.

Słowa kluczowe: blokowanie patentów, licencje, wykluczenia prawne, prawa własności intelektualnej, innowacje, wiedza, licencjonowanie, patenty, transfer technologii, przeniesienia.
\end{abstract}

